\title{
Evaluation of compressive strength of concrete with metakaolin using different
}

\section{levelling techniques}

\author{
Avaliação da resistência à compressão de concreto com metacaulim por diferentes técnicas de \\ capeamento
}

Evaluación de la resistencia a la compresión del hormigón con metacaolín mediante diferentes técnicas de refrentado

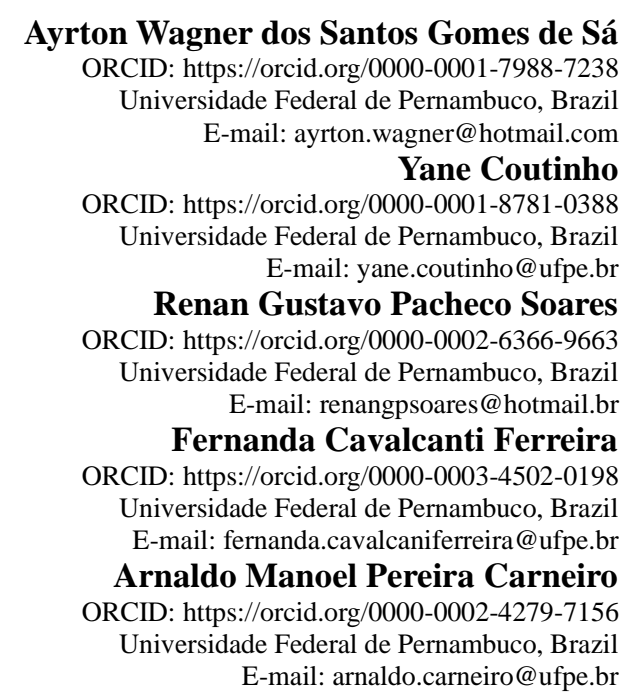

\begin{abstract}
The partial replacement of cement by mineral additions such as metakaolin has been widely applied in the production of high-strength and durable concretes due to the pozzolanic action, allowing a reduction in the consumption of cement. Tests are performed to determine the mechanical properties of these materials, such as compressive strength, for which there are different levelling techniques of specimens, such as sulphur and neoprene, indicated for different resistance classes. The present study aimed to characterize the behaviour, in the hardened state, of concrete produced with high initial strength Portland cement (CPV-ARI) and metakaolin and evaluate the different levelling methods. Three groups of samples dosed by the IPT-EPUSP method, with mix designs of 1:3, 1:5, and 1:6, and replacements of 8 and $10 \%$ of cement by metakaolin, were subjected to compressive strength test, at the ages of 28 days, with levelling by neoprene, and 90 days, with levelling by sulphur. It was observed an increase in strength with addition of metakaolin at both ages. Comparing the results in the two ages, it was verified an increase in strength for the mix designs 1:5 and 1:6 and a reduction for the mix design 1:3. Such fact can be explained by the high strengths achieved by this mix design. As the levelling method used was sulphur, it is confirmed the imprecision of results for strengths above $50 \mathrm{MPa}$ with this technique.
\end{abstract}

Keywords: Concrete; Compressive strength; Metakaolin; Levelling methods.

\section{Resumo}

A adição ou substituição de cimento de modo parcial por adições minerais como o metacaulim tem sido amplamente utilizada na produção de concretos de alta resistência e durabilidade, devido a sua ação pozolânica, permitindo a redução do consumo de cimento. A determinação de propriedades mecânicas para estes materiais é feita através da realização de ensaios, tais como o de resistência à compressão, para o qual há diferentes técnicas de capeamento de corpos de prova, como o enxofre e o neoprene, indicados para diferentes classes de resistência. O presente estudo teve como principal objetivo caracterizar o comportamento, no estado endurecido, de concreto produzido com cimento Portland de alta resistência inicial (CPV-ARI) e metacaulim além de avaliar diferentes métodos de capeamento. Três grupos de amostras dosadas pelo método do IPT-EPUSP, com traços 1:3, 1:5 e 1:6, e substituições de 8 e $10 \%$ de cimento por metacaulim, foram submetidos a ensaio de resistência à compressão, nas idades de 28 dias, com capeamento por neoprene, e 90 dias, por enxofre. Observou-se aumento na resistência com a adição de metacaulim, 
tanto aos 28 quanto aos 90 dias. Comparando-se os resultados nas duas idades, notou-se um aumento na resistência para os traços 1:5 e 1:6 e uma redução para o traço 1:3. Tal fato pode ser explicado pelas altas resistências alcançadas por esse traço. Como o método de capeamento utilizado foi o enxofre, confirma-se sua imprecisão de resultados para resistências acima de $50 \mathrm{MPa}$.

Palavras-chave: Concreto; Resistência à compressão; Metacaulim; Capeamento.

\section{Resumen}

La adición o sustitución parcial de cemento por adiciones minerales como el metacaolín ha sido ampliamente utilizada en la producción de hormigón de alta resistencia y durabilidad, debido a su acción puzolánica, que permite la reducción del consumo de cemento. La determinación de las propiedades mecánicas de estos materiales se realiza mediante ensayos, como la resistencia a la compresión. Para esta prueba, existen diferentes técnicas de refrentado para probetas, como azufre y neopreno, indicadas para diferentes clases de resistencia. El presente estudio tuvo como objetivo principal caracterizar el comportamiento, en estado endurecido, del hormigón producido con cemento Portland de alta resistencia inicial (CPV-ARI) y metacaolín, y evaluar diferentes métodos de refrentado. Tres grupos de probetas dosificadas por el método IPT-EPUSP, con mezclas 1: 3, 1: 5 y 1: 6, y sustituciones de cemento al 8 y $10 \%$ por metacaolín, fueron sometidos a un ensayo de resistencia a la compresión a las edades de 28 días, con refrentado de neopreno, y 90 días, con azufre. Se observó un aumento de la resistencia con la adición de metacaolín, tanto a los 28 como a los 90 días. Al comparar los resultados en las dos edades, hubo un aumento en la resistencia para las mezclas 1: 5 y 1: 6 y una reducción para la mezcla 1: 3. Esto puede explicarse por la alta resistencia lograda por esta mezcla. Como el método de refrentado utilizado fue el azufre, se confirma la inexactitud de los resultados para resistencias superiores a $50 \mathrm{MPa}$.

Palabras clave: Hormigón; Resistencia a la compresión; Metacaolín; Métodos de refrentado.

\section{Introduction}

The development of new technologies aims to improve the performance of products and services and can be focused on the optimization of production processes. In the construction industry, this idea has been applied in diverse segments, for instance project steps, constituent materials, and executive processes.

Among the materials used in this sector, concrete is the most common. The importance of this material is attributed to the compressive strength, versatility of moulding in different formats, relatively low cost, and ease of production (Mehta \& Monteiro 2014). In the concrete matrix, the main element that promotes strength is cement. This material represents a significant parcel in the cost of concrete, and its production requires considerable logistic. The abundant use of Portland cement contributes to the degradation of the environment, as the industrial process liberates a good amount of $\mathrm{CO}_{2}$ in the atmosphere, which is responsible for the depletion of the ozone layer. Thus, any decrease in the production of this gas can have a positive impact considering the sustainable aspect, which can be achieved by reducing cement consumption.

In his regard, the optimization of grain size curves of aggregates is an option (Ferreira, Coutinho \& Carneiro, 2021). Researchers have also developed composite materials of cement base with good performance, by the use of mineral additions, aiming to reduce cement consumption. Silica fume, nanosilica, volcanic ash, fly ash, and metakaolin have been studied as options in the last years (Donatello et al. 2010, Shi et al. 2011, Paiva et al. 2012, Duan et al. 2013, Nadeem et al. 2014, Shi et al. 2015, Kelestemur \& Demirel 2015, Barluenga et al. 2015, Folagbade 2016, Bucher et al. 2017, Wu et al. 2018 , Mastali et al. 2019, Ashish 2019). Such materials are known as pozzolanic materials, because they present in their composition amorphous components that, after calcination and in contact with water, react with calcium hydroxide and form elements with binder properties. Therefore, they enable the reduction of cement consumption in the production of concretes of different resistance classes and applications.

Thus, the present work aimed to characterize the behaviour of concrete in the hardened state, produced with high early strength cement (CPV-ARI) and metakaolin partially replacing cement, and evaluate different levelling methods, such as sulphur and neoprene rubber. 


\subsection{Properties of concrete with metakaolin}

Metakaolin is an amorphous material, with disordered crystalline structure, obtained by an industrial process of thermal activation at 600 and $850{ }^{\circ} \mathrm{C}$ for kaolinitic clays and kaolins, respectively. It is an effective mineral addition for concretes and products with a Portland cement base, and an option in cases where high strength and durability are necessary, as it can elevate the compactness of the system, close the concrete pores, and increase concrete strength (Talero, 2005).

The composition of metakaolin is basically silica $\left(\mathrm{SiO}_{2}\right)$ and alumina $\left(\mathrm{Al}_{2} \mathrm{O}_{3}\right)$, in similar proportions, and other chemical components in the amorphous phase, combined with the calcium hydroxide $\mathrm{Ca}(\mathrm{OH})_{2}$ in the composition of the cement paste. Metakaolin provides a microfiller action, which is the filling of voids present between the cement particles (Ashish, 2019). Shen et al. (2017) indicate that metakaolin has the same efficiency of silica fume. This addition, differently from other mineral additions, is not a secondary industrial waste.

In addition to the sustainable benefits, metakaolin has advantages for the use in concrete. The compressive strength considerably increases, mainly if combined with a superplasticiser admixture. By replacing an amount of cement by metakaolin, there is a reduction in the cement consumption and an increase in the compressive strength. This gain in compressive strength with the use of pozzolanic mineral additions is due to the pozzolanic reactions that occur in the concrete (Bucher et al. 2017). Metakaolin also decreases the porosity of concrete, decreasing tension concentration in the pore surroundings.

According to tests performed by Lacerda \& Helene (2005), mixtures with replacement of metakaolin showed higher longitudinal deformation modulus than the reference concrete. The decrease in pores results in a more rigid concrete, varying the elastic modulus. Abrasion resistance and tensile strength also increase with the addition of metakaolin. According to Ashish (2019), the consumption of calcium hydroxide due to pozzolanic reactions contributes to the increase in compressive strength. This hydroxide in the transition zone is one of the main tensile weakness points of concrete.

The reduction in porosity and capillarity decreases the occurrence of pathological manifestations, such as alkali aggregate reaction and penetration of aggressive agents, such as chlorides and sulphates, increasing the durability of concrete (Wianglor et al. 2017). After the occurrence of pozzolanic reactions, less dense crystals of C-S-H are generated, filling the concrete voids and reducing the pores in the system, avoiding the penetration of agents (Tafraoui et al. 2016).

\section{Methodology}

In this study, materials available in the metropolitan region of Recife were used. The materials used are detailed as follows.

\subsection{Materials}

\subsubsection{Cement}

The cement used in this experimental study was CP V-ARI. The specific gravity test, as described by ABNT NBR 16605:2017, and the fineness test by Blaine method, according to ABNT NBR 16372:2015, were performed, and the values $3.046 \mathrm{~g} / \mathrm{cm}^{3}$ and $457.75 \mathrm{~m}^{2} / \mathrm{kg}$ were obtained, respectively. The material was passed through the sieve with opening of 600 $\mathrm{mm}$.

\subsubsection{Aggregates}

The fine aggregate used was sand from Caxitú river, located in the city of Conde, Paraíba. This material presents specific gravity of $2.65 \mathrm{~g} / \mathrm{cm}^{3}$, fineness index of $2.50 \mathrm{~mm}$ and maximum characteristic dimension of $2.40 \mathrm{~mm}$. 
The coarse aggregates used were obtained by the crushing of granitic stone, a commonly used material in the region. Three different sizes were used: crushed stone 0 (passing in the sieve of opening $12 \mathrm{~mm}$ ), crushed stone 1 (passing in the sieve of opening $24 \mathrm{~mm})$, and stone powder $(<5 \mathrm{~mm})$.

\subsubsection{Metakaolin}

The metakaolin used in the present study had orange colour and fine grain size.

\subsubsection{Admixture}

The admixture used for the test with cement paste, produced by ADITEX, was the AD-flux PCE 01, which is a synthetic polymer, hiperplasticiser, used as dispersant to cement systems, aiming to produce a reduction up to $50 \%$ in the water used, according to the producer, and improve the mechanical properties of mortars due to a better cement hydration. The dosage recommended by the producer is from $0.05 \%-0.60 \%$ related to the cement mass.

\subsection{Methods}

In the experimental study, three different proportions of cement and aggregate - 1:3, 1:5 and 1:6 - were used with and without addition of metakaolin.

\subsubsection{Dosage of concrete}

The concrete was prepared in the anhydrous state for the mix designs 1:3, 1:5, 1:6, with and without metakaolin, totalizing six mixtures. In the experimental study of fresh concrete, a mortar content of $60 \%$ was fixed. Table 1 presents the proportions of materials for each mix design.

Table 1. Mix designs studied for concretes produced.

\begin{tabular}{|c|c|c|c|c|c|c|c|c|}
\hline & C: Ag. & Cement & Metakaolin & Sand & $\begin{array}{c}\text { Stone } \\
\text { Powder }\end{array}$ & $\begin{array}{c}\text { Crushed } \\
\text { stone } 0\end{array}$ & $\begin{array}{c}\text { Crushed } \\
\text { stone } 1\end{array}$ & $\mathrm{~W} / \mathrm{C}$ \\
\hline G3 & $1: 3$ & 1 & 0 & 1.4 & 0.8 & 0.32 & 0.48 & 0.41 \\
\hline G5 & $1: 5$ & 1 & 0 & 2.6 & 1.2 & 0.48 & 0.72 & 0.57 \\
\hline G6 & $1: 6$ & 1 & 0 & 3.2 & 1.4 & 0.56 & 0.84 & 0.67 \\
\hline G3M & $1: 3$ & 0.92 & 0.08 & 1.4 & 0.8 & 0.32 & 0.48 & 0.44 \\
\hline G5M & $1: 5$ & 0.92 & 0.08 & 2.6 & 1.2 & 0.48 & 0.72 & 0.62 \\
\hline G6M & $1: 6$ & 0.92 & 0.08 & 3.2 & 1.4 & 0.56 & 0.84 & 0.72 \\
\hline Y3 & $1: 3$ & 1 & 0 & 1.4 & 0.64 & 0.48 & 0.48 & 0.38 \\
\hline Y5 & $1: 5$ & 1 & 0 & 2.6 & 0.96 & 0.72 & 0.72 & 0.52 \\
\hline Y5 & $1: 6$ & 1 & 0 & 3.2 & 1.12 & 0.84 & 0.84 & 0.61 \\
\hline Y3M & $1: 3$ & 0.92 & 0.08 & 1.4 & 0.64 & 0.48 & 0.48 & 0.38 \\
\hline Y5M & $1: 5$ & 0,92 & 0.08 & 2.6 & 0.96 & 0.72 & 0.72 & 0.52 \\
\hline Y6M & $1: 6$ & 0.92 & 0.08 & 3.2 & 1.12 & 0.84 & 0.84 & 0.61 \\
\hline A3 & $1: 3$ & 1 & 0 & 1.4 & 0.8 & 0.32 & 0.48 & 0.4 \\
\hline A5 & $1: 5$ & 1 & 0 & 2.6 & 1.2 & 0.48 & 0.72 & 0.51 \\
\hline A6 & $1: 6$ & 1 & 0 & 3.2 & 1.4 & 0.56 & 0.84 & 0.6 \\
\hline A3M & $1: 3$ & 0.9 & 0.1 & 1.4 & 0.8 & 0.32 & 0.48 & 0.4 \\
\hline A5M & $1: 5$ & 0.9 & 0.1 & 2.6 & 1.2 & 0.48 & 0.72 & 0.51 \\
\hline A6M & $1: 6$ & 0.9 & 0.1 & 3.2 & 1.4 & 0.56 & 0.84 & 0.6 \\
\hline
\end{tabular}

Source: Authors.

\subsubsection{Grain size composition test}

The mechanical grain size composition test was used to determine the grain size distribution of concrete in the 
anhydrous state, following test method ABNT NBR 7217:1987. In this test, the normal series of sieves was used together with the sieve of opening $75 \mu \mathrm{m}$.

\subsubsection{Unit weight}

The unit weight was used as a parameter to classify the aggregate or mixture regarding its density, following ABNT NBR NM 45:2006.

\subsubsection{Levelling}

The test method ASTM C 39 (ASTM 2003) requires that the edges of the specimens are rectified or levelled such that the loading surfaces are plane within $0.05 \mathrm{~mm}$ and perpendicular to the longitudinal axis of specimens with maximum deviation of $0.5^{\circ}$. According to the Brazilian test method NBR 5738:2015 (ABNT 2015), the levelling consists of the coating of the top of specimens with a fine layer of proper material. Among the available options, it was used sulphur and neoprene rubber as levelling methods.

\subsubsection{Sulphur levelling}

According to Bucher and Rodrigues Filho (1983), the levelling with a mixture of sulphur and inert filler has as advantage the ease of application, although its handling is dangerous, requiring security measures.

For the execution of the levelling paste, it was used a mix design of 3:1 (sulphur: cement), heated until complete melting of sulphur and obtainment of a homogeneous mixture of materials.

\subsubsection{Neoprene rubber}

The elastomer type neoprene is the most used material of non bonded system, characterized by the use of a material as a cushion to the bases of the specimens, being the material confined or not (Barbosa et al. 2009).

\subsubsection{Compressive strength of specimens}

The procedures for moulding of specimens were performed according to test method NBR 5738:2015. A total of 60 cylindrical specimens with dimensions $10 \times 20 \mathrm{~cm}$ were moulded, 20 of each mix design (1:3, 1:5, and 1:6). Among those, half had addition of metakaolin.

According to the procedures of NBR 5739:2007 for rupture of specimens, tests were performed at 28 and 90 days, using levelling by neoprene and sulphur, respectively. A press of Instron model was used, with loading capacity of 300 tons.

\section{Results and Discussion}

From the tests performed, it was possible to determine the grain size distribution curves of the concrete in the anhydrous state for the mix designs used. From Figure 1, it can be seen that the grain size distribution curves for the mix designs with metakaolin have a lower amount of fines compared to the curves without metakaolin. As metakaolin is a material with a larger surface area than cement, consequently a finer material, the opposite was expected. This may be a result of insufficient sieving time, which was 7 min for each sample. As there was no previous sieving of the metakaolin sample, agglomerated particles were removed, which may have caused the results in Figure 1. 
Figure 1. Grain size curve of dry samples.

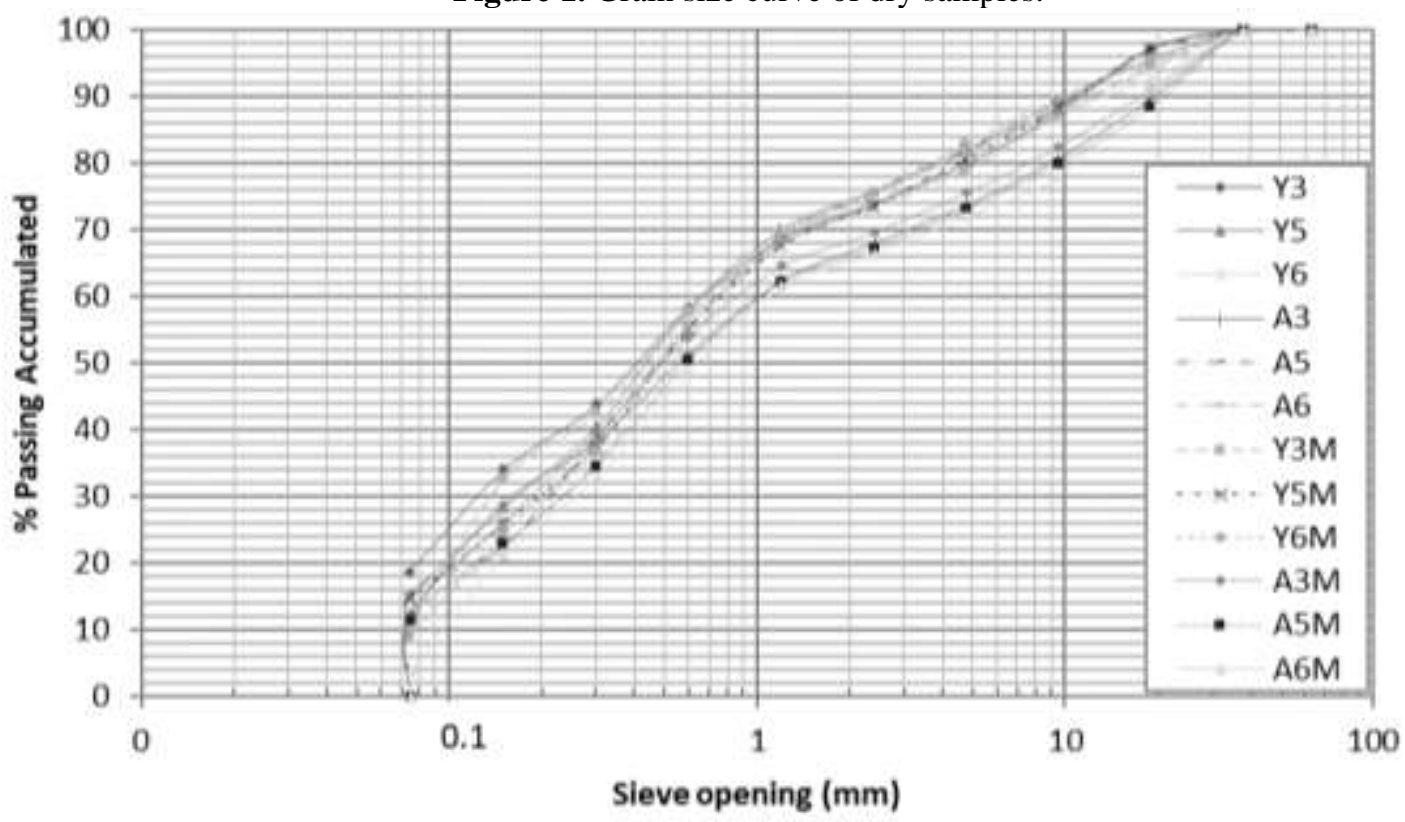

Source: Authors.

The grain size distribution of the concrete in the anhydrous state for all mix designs, as shown in Figure 1, does not exhibit a continuous grain size distribution or a maximum compactness, as it is notorious the presence of a shoulder in the curve between the range of $0.3 \mathrm{~mm}$ to $2.4 \mathrm{~mm}$, which is precisely the grain size band that can be attributed to stone powder.

As for the behaviour of the mix designs in the hardened state, Table 2 shows the results of compressive strength obtained at 28 and 90 days, with and without replacement of cement by metakaolin. The results correspond to the average obtained using at least three specimens.

Table 2. Results of compressive strength.

\begin{tabular}{|c|c|c|c|c|c|}
\hline \multirow{2}{*}{ Name } & \multirow{2}{*}{ Metakaolin } & \multirow{2}{*}{ 1:M } & \multicolumn{2}{|c|}{ Strength } & \multirow{2}{*}{ W/C } \\
\hline & & & 28 DAYS & 90 DAYS & \\
\hline G3 & 0 & $1: 3$ & 47.00 & 45.10 & 0.41 \\
\hline G5 & 0 & $1: 5$ & 25.45 & 27.35 & 0.57 \\
\hline G6 & 0 & $1: 6$ & 19.20 & 23.22 & 0.67 \\
\hline G3M & 0.08 & $1: 3$ & 55.89 & 46.02 & 0.44 \\
\hline G5M & 0.08 & $1: 5$ & 42.31 & 42.80 & 0.62 \\
\hline G6M & 0.08 & $1: 6$ & 29.51 & 33.12 & 0.72 \\
\hline Y3 & 0 & $1: 3$ & 64.46 & 61.81 & 0.38 \\
\hline Y5 & 0 & $1: 5$ & 27.63 & 35.06 & 0.52 \\
\hline Y6 & 0 & $1: 6$ & 23.73 & 27.03 & 0.61 \\
\hline Y3M & 0.08 & $1: 3$ & 81.94 & 61.05 & 0.38 \\
\hline Y5M & 0.08 & $1: 5$ & 43.70 & 42.89 & 0.52 \\
\hline Y6M & 0.08 & $1: 6$ & 34.18 & 36.68 & 0.61 \\
\hline A3 & 0 & $1: 3$ & 72.13 & 66.24 & 0.4 \\
\hline A5 & 0 & $1: 5$ & 28.17 & 32.65 & 0.51 \\
\hline A6 & 0 & $1: 6$ & 26.15 & 23.67 & 0.6 \\
\hline A3M & 0.1 & $1: 3$ & 67.19 & 56.04 & 0.4 \\
\hline A5M & 0.1 & $1: 5$ & 52.30 & 49.78 & 0.51 \\
\hline A6M & 0.1 & $1: 6$ & 36.38 & 38.10 & 0.6 \\
\hline
\end{tabular}

Source: Authors.

The analysis of variance (ANOVA) of one variable was used to verify the influence of replacement and percentage of 
addition, mix design and type of levelling on the results of compressive strength, indicating or not statistical equality of the data. For this study, a significance of 0.05 was adopted, such that the results of the analyses present a reliability of $95 \%$. If there is no statistical equality, it means that one variable is related to the other. If there is equality, the results do not present a significant difference for that variable.

The mix designs 1:3, 1:5, and 1:6 significantly influenced the results of compressive strength. All analyses returned Pvalues lower than 0.05 . In fact, the mix design 1:3 has a higher amount of binder and uses a lower w/c ratio in relation to the mix designs 1:5 and 1:6. Consequently, it has a higher compressive strength.

By comparing the same mix designs, only with or without replacement of cement by addition, the mix designs with addition presented higher results of compressive strength. The analysis of variance of this factor confirmed the influence of the presence of metakaolin in the results, except between the mix designs G903 and G903M, Y283 and Y283M, Y285 and Y285M, A903 and A903M. It is observed that this occurred in G903, G903M, A903 and A903M due to the levelling used in the mix design 1: 3 at 90 days, performed with sulphur, which is not indicated for samples with high strength. In Y283 and Y283M, Y285 and Y285M, the addition did not promote significant difference for the strength results for the significance adopted.

The G and A mix designs were chosen because they had the same granular framework and similar w/c ratio to verify the influence of the percentage of metakaolin replacement in 8 and 10\%. The ANOVA showed that for all strength results at 28 days, the increase in addition promoted better results. At 90 days the results tended to approach more in the mix designs 1:3 and 1:5, reaching a statistical equality.

Mix designs $G$ and $A$ had different types of levelling. G mix designs used sulphur levelling in all samples. In mix designs A, neoprene was used at 28 days and sulphur at 90 days. As the mix designs and w/c ratios were similar, a significant difference between the results of compressive strength at 28 days would be due to the type of levelling used. Therefore, the ANOVA between the results at 28 days of the same mix designs was performed to verify if there was a statistically significant difference in the compressive strength due to levelling. According to Table 3, for all mix designs, the type of levelling had a significant influence on the strength results, except for G286 and A286, poor mix designs, whose compressive strengths were below $30 \mathrm{MPa}$.

Table 3. ANOVA for levelling.

\begin{tabular}{cccccccc}
\hline Variable & SQ & LG & MQ & F & P-Value & Critical F & Influence \\
\hline G283 - A283 & 1264.04 & 1 & 1264 & 348.79 & $2 E-06$ & 5.9874 & YES \\
\hline G285 - A285 & 14.79 & 1 & 14.79 & 29.27 & 0.0016 & 5.9874 & YES \\
\hline G286 - A286 & 34.57 & 1 & 34.57 & 1.96 & 0.2107 & 5.9874 & NO \\
\hline G283M - A283M & 255.56 & 1 & 255.56 & 18.99 & 0.0048 & 5.9874 & YES \\
\hline G285M - A285M & 199.76 & 1 & 199.76 & 44.20 & 0.0006 & 5.9874 & YES \\
\hline G286M - A286M & 94.41 & 1 & 94.41 & 84.42 & $9 E-05$ & 5.9874 & YES \\
\hline
\end{tabular}

Source: Authors.

The unit weight of the $\mathrm{Y}$ and $\mathrm{A}$ mix designs was also performed in the anhydrous state to verify the compactness of the materials and the influence of metakaolin in this property. The results are shown in Table 4. 
Table 4. Results of unit weight.

\begin{tabular}{cccc}
\hline Name & Metakaolin & Mix Design & Unit weight $\left(\mathbf{k g} / \mathbf{m}^{\mathbf{3}}\right)$ \\
\hline Y3 & 0 & $1: 3$ & 1686.70 \\
\hline Y5 & 0 & $1: 5$ & 1807,00 \\
\hline Y6 & 0 & $1: 6$ & 1794.30 \\
\hline Y5M & 0.08 & $1: 3$ & 1634.30 \\
\hline Y6M & 0.08 & $1: 5$ & 1747.00 \\
\hline A3 & 0.08 & $1: 6$ & 1773.00 \\
\hline A5 & 0 & $1: 3$ & 1720.00 \\
\hline A6 & 0 & $1: 5$ & 1809.67 \\
\hline A3M & 0 & $1: 6$ & 1814.33 \\
\hline A5M & 0.1 & $1: 3$ & 1609.00 \\
\hline A6M & 0.1 & $1: 5$ & 1734.67 \\
\hline
\end{tabular}

Source: Authors.

It can be seen that, for the same mix designs, there is a decrease in unit weight when cement is replaced by metakaolin, which was expected as metakaolin has a higher specific surface area than cement. The ANOVA results, presented in Table 5, confirmed the influence of addition on the unit weight, except between Y906 and Y906M, which presented statistical equality.

Table 5. ANOVA for the unit weight.

\begin{tabular}{ccccccccc}
\hline Variable & SQ & LG & MQ & F & P-Value & \multicolumn{2}{c}{ Critical F } & Influence \\
\hline A903 - A903M & 18482 & 1 & 18482 & 362.38 & 4 E-05 & 7.7086 & YES \\
\hline A905 - A905M & 8437.5 & 1 & 8437.5 & 18.571 & 0.0126 & 7.7086 & YES \\
\hline A906 - A906M & 12240 & 1 & 12240 & 91.572 & 0.0007 & 7.7086 & YES \\
\hline Y903 - Y903M & 4108.2 & 1 & 4108.2 & 12.325 & 0.0247 & 7.7086 & YES \\
\hline Y905 - Y905M & 5400 & 1 & 5400 & 7.9179 & 0.0481 & 7.7086 & YES \\
\hline Y906 - Y906M & 682.67 & 1 & 682.67 & 2.7288 & 0.1739 & 7.7086 & NO \\
\hline
\end{tabular}

Source: Authors.

Comparing the values obtained in relation to the different mix designs, there is a tendency of increasing the unit weight as the cement quantity decreases in relation to the quantity of aggregates, except for the mix designs Y5 and A5M, which can be an indicator that these mix designs are more compact than the others. The analysis of variance confirms this tendency, showing a significant difference between the data analysed, and it can be concluded that the mix design influenced the results of unit weight to a significance of 0.05 .

\section{Conclusion}

In the results obtained for compressive strength, it can be noticed that the specimens with addition of metakaolin did not present a significant gain of compressive strength at 90 days related to the results obtained at 28 days. Some exhibited a decrease in the strength. However, some factors hinder a direct correlation between the two results, as the rupture at 28 days used neoprene and not the sulphur levelling that was used at 90 days.

In general, by analysing only the data obtained at 90 days, it was observed that they are consistent with the literature, as the mix designs with addition of metakaolin presented a gain in the strength compared to those without addition. The increase in the replacement of metakaolin, from 8 to $10 \%$, promoted better results of compressive strength at 28 days.

The unit weight test showed that the mix designs with addition of metakaolin, due to the higher fine content, higher specific surface, and less space occupied in the anhydrous state, presented lower results of unit weight, compared to the same 
mix designs without addition.

The comparison between mix designs G and A by ANOVA indicated that the type of levelling, sulphur or neoprene, influenced the results of compressive strength. Therefore, it was observed a need to use an adequate levelling method to obtain reliable results for the performed tests.

The present study used different levelling techniques for different specimen ages. Therefore, studies should perform compressive tests in specimens at 28 and 90 days using the same levelling techniques, to further analyse their influence.

\section{References}

Ashish, D. K. (2019). Concrete made with waste marble powder and supplementary cementitious material for sustainable development. Journal of Cleaner Production, 211, 716-729.

American Society for Testing and Materials (2017). ASTM C618-17a - Standard specification for coal fly ash and raw or calcined natural pozzolan for use in concrete. West Conshohocken, PA, USA.

American Society for Testing and Materials (2018). ASTM C39/C39M-18 - Standard test method for compressive strength of cylindrical concrete specimens. West Conshohocken, PA, USA.

American Society for Testing and Materials (2015). ASTM C1231/C1231M-15 - Standard practice for use of unbonded caps in determination of compressive strength of hardened cylindrical concrete specimens. West Conshohocken, PA, USA.

Associação Brasileira de Normas Técnicas (2015). NBR 5738:2015 - Concrete - Procedure for molding and curing concrete test specimens. Rio de Janeiro, Brazil.

Barbosa, F. R, Mota, J. M. F, Costa e Silva, A. J., \& Oliveira, R. A. (2009) Análise da Influência do Capeamento de Corpo-de-Prova Cilíndrico na Resistência à Compressão do Concreto. Proceedings: $51^{\circ}$ Congresso Brasileiro de Concreto.

Barluenga G., Palomar I. \& Puentes J. (2015). Hardened properties and microstructure of SCC with mineral additions. Construction and Building Materials, $94,728-736$.

Bucher, H. R. E. \& Rodrigues Filho, H. C. (1983) Argamassas de enxofre para capeamento de corpos de prova. Seminário sobre controle de resistência do concreto, IBRACON, São Paulo.

Bucher R., Diederich P., Escadeillas G., \& Cyr M. (2017). Service life of metakaolin-based concrete exposed to carbonation Comparison with blended cement containing fly ash, blast furnace slag and limestone filler. Cement and Concrete Research, 99, 18-29.

Comité Mercosur de Normalización (1996). Hormigón - Preparación de las bases de probetas y testigos cilíndricos para el ensayo de compresión.

Donatello S. \& Tyrer M., Cheeseman C.R (2010). Comparison of test methods to assess pozzolanic activity. Cement and Concrete Composites, 32 , $121-127$.

Duan P., Shui Z., Chen W., \& Shen C. (2013). Efficiency of mineral admixtures in concrete: Microstructure, compressive strength and stability of hydrate phases. Applied Clay Science, 83-84, 115-121.

Ferreira, F. C., Coutinho, Y., \& Carneiro, A. M. P. (2021). Evaluation of mechanical properties of concrete produced with binary and ternary mixtures of aggregate. Research, Society and Development, 10(1), e43410111948. 10.33448/rsd-v10i1.11948. https://rsdjournal.org/index.php/rsd/article/view/11948. Access: 26 Feb. 2021.

Folagbade, S.O. (2016). Absorption characteristics of cement combination concrete containing portland cement, fly ash, and metakaolin. Civil Engineering Dimension, 18, 57-64.

Kelestemur O., Demirel B. (2015). Effect of metakaolin on the corrosion resistance of structural lightweight concrete. Construction and Building Materials, $81,172-178$.

Mastali M., Dalvand A., Sattarifard A.R., Abdollahnejad Z., Nematollahi B., Sanjayan J.G., \& Illikainen M. (2019). A comparison of the effects of pozzolanic binders on the hardened-state properties of high-strength cementitious composites reinforced with waste tire fibers. Composites Part B, 162, $134-153$.

Mehta P. K. \& Monteiro P. J. M. (2014). Concreto: estrutura, propriedades e materiais. PINI.

Nadeem A., Memon S. A., \& Lo T. Y. (2014). The performance of fly ash and metakaolin concrete at elevated temperatures. Construction and Building Materials, 62, 67-76.

Paiva H., Velosa A., Cachim P., \& Ferreira V. M. (2012). Effect of metakaolin dispersion on the fresh and hardened state properties of concrete. Cement and Concrete Research, 42, 607-612.

Shen P., Lu L., Chen W., Wang F., \& Hu S. (2017). Efficiency of metakaolin in steam cured high strength concrete. Construction and Building Materials, 152, 357-366.

Shi X., Yang Z., Liu Y., \& Cross D. (2011). Strength and corrosion properties of portland cement mortar and concrete with mineral admixtures. Construction and Building Materials, 25, 3245-3256. 
Research, Society and Development, v. 10, n. 3, e31510313341, 2021

(CC BY 4.0) | ISSN 2525-3409 | DOI: http://dx.doi.org/10.33448/rsd-v10i3.13341

Shi Z., Shui Z., Li Q., \& Geng H. (2015). Combined effect of metakaolin and sea water on performance and microstructures of concrete. Construction and Building Materials, 74, 57-64.

Tafraoui A., Escadeillas G., \& Vidal T. (2016). Durability of the ultra-high performances concrete containing metakaolin. Construction and Building Materials, 112, 980-987.

Talero, R. (2005). Performance of metakaolin and portland cements in ettringite formation as determined by ASTM C 452-68: kinetic and morphological differences. Cement Concrete Research, 35(7), 1269-84.

Wianglor K., Sinthupinyo S., Piyanworapaiboon M., \& Chaipanich A. (2017). Effect of álcali-activated metakaolin cement on compressive strength of mortars. Applied Clay Science, 141, 272-279.

Wu J., Zhang Z., Zhang Y., \& Li D. (2018). Preparation and characterization of ultra-lightweight foamed geopolymer (UFG) based on fly ash-metakaolin blends. Construction and Building Materials, 168, 771-779. 